\title{
WATER-MASS EFFECTS AND SEQUENCE BOUNDARIES IN THE LATE MIOCENE OF THE GULF OF MEXICO
}

\author{
GODFREY, Woodson M., PaleoSource, P. O. Box 539, Barker, TX 77413- \\ 0539
}

Since at least the Late Eocene, the Gulf of Mexico has a record of rapid foraminiferal changes found directly immediate to dramatic, widespread unconformities. Several such "events" are closely spaced in time and vertical distance in the Late Miocene offshore Gulf of Mexico, between the extinctions of Catinaster coalitus and Discoaster berggrenii.

Within the sampling scale commonly used for the energy industry (30 foot composite samples), changes in foraminiferal composition (apparent deepening) and sharp increases in faunal and floral abundance are found immediately below or concurrent to unconformable, often paraconformable, surfaces and/or periods of rapid deposition and outbuilding.

The composition of these foraminiferal faunas include abundances of the species Orbulina universa, Globigerina nepenthes and Globigerinoides mitra. This composition is consistent with cool surface waters and upwelling. The benthic foraminifera found with the above planktonics are often included in a list of abyssal species, but fail to have a persistent occurrence in many locations. The "anomalous" occurrence of deep water species does coincide with temperature decreases in deep water as indicated by changes in the stable oxygen isotope record.

The above events are interpreted to be the result of shallowing thermoclines just prior or concurrent to eustatic lowstands. Foraminiferal abundances and anomalous "deep water" faunas are indicative of shoaling water masses below the thermocline and productivity increases during upwelling when the thermocline is broken.

The probable mechanism for producing such events may found in recent subsea topography and current patterns. Prior to eustatic lowstands, strengthened deep-water currents enter from the Caribbean. The increased volume of cold water "piles up" in the northern end of the basin without sufficient means of exit. Warmer surface waters are displaced and the thermocline elevates. Shoaling cold water masses carry their foraminiferal faunas with them. 